\title{
Understanding Corporate Bonds, Interest Rates, and Issuance Prices
}

\author{
Donald T. Joyner ${ }^{1} \&$ Carl B. McGowan, Jr. ${ }^{1}$
}

\author{
${ }^{1}$ Norfolk State University, Norfolk, VA 23504, USA. \\ Correspondence: Carl B. McGowan, Jr., AFMIS, Norfolk State University, Norfolk, VA 23507, USA. \\ cbmcgowan@yahoo.com, 757-275-6876 \\ Received: February 15, 2015 \\ Accepted: April 8, 2015 \\ Available online: July 22, 2015 \\ doi:10.11114/afa.v1i2.682 \\ URL: http://dx.doi.org/10.11114/afa.v1i2.682
}

\begin{abstract}
Businesses evolve over time and the degree of risk and the needs for financing evolve, too. In the early stages of a business, the business is small and most of the financing comes from the entrepreneur and from retained earnings of the business. After a business achieves a certain size, external financing is needed such as venture capital, new stockholders' equity, and bonds. Over the last one hundred years, individuals providing external funding to businesses have demanded more and better information. Currently, Sarbanes-Oxley requires both information and evidence that the information is correct. Thus, companies are required to have internal controls that validate the information provided to stakeholders and to have the auditors confirm the quality of the internal control mechanisms.
\end{abstract}

Keywords: Risk and return, business growth, sole proprietorship, corporation, equity financing, bond financing, Sarbanes-Oxley, required rate of return

\section{Introduction}

\section{1 Evolution of a Business}

During the life of a business, the business goes through several phases. Although every business does not follow the same path, the order in which the business evolves often follows this pattern: First, a single individual may start a sole proprietorship. The sole proprietorship may be a business based on a desire to earn an income based on an original idea. If the business is successful, the next logical step is to expand. The expansion can be done by borrowing from a bank or bringing in a partner or partners. For the sake of simplicity, assume that the business grows by admitting partners.

At this point the business would become a partnership. Admitting partners helps the business grow in two ways. First, it brings in additional skill sets. For example, the originator of the business may be able to produce quality products, but lack marketing skills. In such a situation it would make sense to combine forces with someone who has expertise in marketing. Second, new partners also contribute additional funding. While it is possible that the founder of the business may admit a partner based solely on the skills the new partner brings to the business, usually a new partner contributes additional funding. However, survival often depends on funding. Talent and skills are often not enough to make a business viable for the long-term. Ultimately, it takes financing to remain competitive.

Consequently, the next step in a business's growth is to bring in a large amount of funding. This is often the point at which a business seeks out venture capitalists. Venture capitalists are individuals who possess large amounts of personal funds. If a partnership has proven successful and viable, a venture capitalist would be motivated to lend funds to the business at a high rate of interest.

During the business's growth, borrowing money has always been an option. This could have taken place at either the sole proprietorship or partnership stages of the business. It definitely occurs at the point where the business's owners are ready to solicit funding from venture capitalists. It should be noted that the participation of a venture capitalist does not change the form of the business. If the business is a sole proprietorship when a venture capitalist becomes involved, it remains a sole proprietorship. If the business is a partnership when a venture capitalist becomes involved it remains a partnership.

\section{Corporations}

The beginning of this paper addressed the steps of evolution a growing business undergoes. It ended at the point where 
the business seeks venture capitalists to provide funding for even further growth. If the business is successful, it will continue past the venture capitalist stage. Presumably, the influx of capital provided by the venture capitalist was used wisely and the business continued its growth. Eventually, the venture capitalist's loan will be paid in full with interest. It should be noted that this discussion pertains to a business that has grown to be very large and is now at the stage where it is ready to become a corporation and issue stock.

Despite commericials that promise protection of personal assets in the event a lawsuit arises as a result of their business' operations, the fact remains that shares of ownership in the business are still risky. A sole proprietor can file to be recognized as a corporation, but if all shares of stock are still held by the same individual, there is not really any differentiation in fact. Simply calling the business a corporation does not give its owner a free pass to do whatever they please without worry of any personal financial consequences.

If an individual or partners decide that their company has grown as much as possible and their business has continued to thrive at every stage and has paid off venture capitalists, what is the next logical step? The answer is to formally turn the business into a corporation.

In this case, assume that the business is very large and it intends to go public. If that is the case, the business will hire legal counsel and undergo a process in which articles of incorporation are filed in the state in which the corporation is headquartered. The articles of incorporation define how the business is to be operated. It also establishes the number of shares of ownership a corporation can issue. Shares of ownership take two forms. Common Stock entitles the owner to vote on corporate matters at the annual meeting and a share of corporate profits which are paid out in the form of dividends. Preferred Stock entitles the owner only a predetermined amount of dividends. Also, if the corporation goes bankrupt, when debts are settled, preferred stockholders must be paid before any amount can go to common shareholders. Preferred stock resembles a borrowing financial instrument more than it does a share of ownership. A preferred shareholder is owed only a predefined amount of dividends. A common shareholder's dividends, in theory, have no limit.

The original owner(s) of the business have an incentive to form a publicly traded corporation. First, the fact that ownership and control is spread out over a large number of shareholders, personal liability is greatly reduced, if not eliminated. Second, a corporation can only borrow a finite amount of money. In order to generate massive amounts of capital, 'investors' require more than a pre-defined amount of interest. In order to entice individuals to invest more than they would in a traditional borrowing, they need to be guaranteed a share of the profits generated. Therefore, offering shares of ownership solves that problem.

\section{Lessons Learned from History}

The American Stock Market Crash of 1929 is an example of simply betting on corporations with virtually no knowledge of the actual status or probable outcomes associated with each business. That is gambling. In retrospect it should have been obvious that the worth of all businesses could not be increasing at the same time. Nevertheless, everyone kept buying more and more stock. The outcome was the same as it is with all gambling, eventually the bettor will lose everything if they keep playing.

In a capitalist economic system like that in the United States, risk has always been a part of the equation. Not every business arrangement has to have a 'winner' and a 'loser.' Often, both parties in a business transaction benefit. America is called the 'Land of Opportunity' for a reason. Though it is an idealized portrayal of America, new immigrants to America, arriving at Ellis Island, with literally nothing but the clothes they are wearing, have in fact become multimillionaires. Even in present-day America, teenagers have become millionaires. There is even the concept of the 'American Dream' in which an individual simply holds a normal job, makes a comfortable income (by American standards), has a spouse, children, a nice home, and a white pickett fence surrounding it all.

While the concept of the 'American Dream' is a romanticized concept of capitalism, it does reflect fundamental truths of the American economy. The earliest settlers of America focused mainly on businesses rooted in agriculture. For the most part the economy was simple. However, as the American economy evolved, so did the demand for items other than food and tobacco. Business in America has steadily evolved into an extremely complex capitalist economy.

Risk has evolved as the American economy has evolved. The stock market crash of 1929 was not the first financial crash in American history. In 1849 there was the famed gold rush in California. Interestingly, some aspects of the gold rush still apply to the American business climate of today. The gold rush started when gold was discovered in California. Many people immediately rushed to California to 'strike it rich.' The problem with that line of reasoning is the presumption that there is plenty of gold and there are few people looking for it. In reality, the easiest gold to mine had already been extracted and the places where gold had been found were hopelessly overcrowded by the time a prospective miner arrived in California. In today's economy there is the concept of the 'hot stock tip.' Just like gold, this information entices people to invest without considering all the factors involved. In reality, by the time an individual 
hears of a 'hot stock tip' any profit that could be acquired by purchasing the stock low and selling it high has already been realized by earlier investors.

By the time of the American Civil War, the economy of the United States was becoming more industrialized, especially in the north. Prior to industrialization, most businesses were regional in nature. When people invested money in a business, the owner(s) of the business were usually friends, family, or at the very least, people who lived nearby. Investors did not have to worry about whether the business was being run properly, because they had easy access to the actual business. These sorts of arrangements/situations began to disappear as businesses grew in scope. Perhaps the best example of such businesses were cross-country railroads. The investors in such a business did not live nearby nor could they easily observe whether the business was being run properly.

As a result, the need for the audit profession emerged. Owners needed aueditors to go to a business's headquarters to examine the results of its operations and whether money was being handled properly. Investors did not have the time or the ability to travel long distances to monitor their investments. So, collectively, they would hire auditors to provide assurances for them.

The need for audits was recognized, but the absolute necessity of them was not recognized until after the crash of 1929 . Prior to the crash of 1929, public companies did not have to provide audited financial statements to the public. In fact, 1929 was not even the first major market crash. Twenty years prior, there was the crash of 1909. Unfortunately, this did not result in the realization that audits were a necessity. However it did prompt the creation of Standard and Poors. Though not an auditing agency, Standard and Poors was formed to analyze companies and assess their creditworthiness. Standard and Poors is still in existence today and is a premier source for assessing the creditworthiness of debt issuances. Unfortunately the 1909 crash did not lead to the realization that the investing public needed to be provided audited financial statements. As a result whatever financial statements investors were provided, if any, carried no guarantee as to their accuracy. It is very easy to make up numbers so that the financial statements depict a positive image of a company when in reality the company is a disaster. Only audited and accurate financial statements can provide accurate information as to the status of a business. For example, one could view a restaurant with a high volume of customers. Further, every customer may say positive things about the restaurant. Consequently, one may feel that the business is making large profits. In reality, businesses are much more complex. The restaurant may appear successful, but in fact it may be losing large amounts of money. Audited financial statements provide information that one cannot obtain by mere observation.

In response to financial fiascos, the United States Congress has passed the The Securities Act of 1933 and the Securities and Exchange Commission Act of 1934. The latter law required mandatory audited financials for companies that are initially going public and companies that trade on the national exchanges respectively. In 2002, the Sarbanes-Oxley Act was passed. The goal of this legislation was to make audits more dilligent.

Business risk can never be eliminated. There will always be business risk due to information assymetry. Information assymetry occurs because the public does not have instantaneous knowledge of every event which impacts a particular business. Shareholders in the company do not have instant access to information and a company's creditors do not have instant access to information. Information can be obtained throughout a year. People then speculate on stock prices and risks associated with different companies. This speculation impacts both the stock price and interest rates in regards to a business. If people are optimistic about a company, this optimism would be reflected by a higher stock price and a lower interest rate charged by creditors. If people are not optimisitic about a company, this pessimism would be reflected by a lower stock price and a higher interest rate charged by creditors.

With respect to accounting, accounting sets the rules by which companies are judged. Generally Accepted Accounting Principles (GAAP) outline how a company should report the results of its operations. In theory, an independent auditor should examine a company's internal records and issue an opinion on whether a company has issued financial statements which conform to GAAP. Auditors do not express an opinion on whether a company is a good investment in terms of buying shares of ownership or whether it is wise to lend the company money. An audit opinion only expresses whether or not a company's financials are accurate and reliable, i.e. conform to GAAP, or whether they are not accurate or reliable. Consequently, an auditor may express a positive opinion on a company's financial statements even if the company is reporting poor results.

While not perfect, the United States has the most highly developed set of accounting standards in the world. One reason for this is the fact that the accounting profession was allowed to set United States accounting standards. The legislative body of the United States declined to interefere in the process. This was a wise decision. Legislative bodies typically consist of individuals who do not have an accounting background or accounting education. Consequently, by letting accountants develop American accounting standards, the resulting accounting system has proven to be more robust and helpful from a decision-making standpoint. As a result, the United States economy is the strongest in the world. 


\section{Risk}

The basic nature of capitalism is, at its core, rooted in two fundamental concepts: profit and risk. Profit is the amount by which a business's income exceeds its expenses. In order to earn money, you have to spend money. Hence the common saying: "it takes money to make money." Regardless of the source of a business's initial funding and subsequent expansions, money has to be put into the business. This is where the concept of risk becomes a factor. There is no guarantee as to whether or not a business will be profitable. Hypothetically, a business could increase in value or the business could go bankrupt within a relatively short time frame.

In regards to borrowing, risk is reflected in the interest rate a lender charges a buyer. Risk is actually quantified and is the determinant of interest rate. In a free market, lenders study a business's profit. Specifically, lenders are interested in the probability that profit will be positive and if so, the amount of the profit. The lender's main concern is the return of the principal amount lent to the borrower. However, simply recouping the amount lent is not the objective. The objective is to earn a positive rate of return on the investment.

In order to fully appreciate the concept of interest rates, it is important to understand how interest rates are determined. A company that has yet to graduate to being a corporation has limited sources from which to borrow. The primary source of funding would be a bank. However, banks follow procedures in regard to whom they will lend and at what interest rate. A venture capitalist uses different criteria. Venture capitalists are willing to accept more risk but require a higher rate of return than a bank lender. Venture capitalists understand that every investment may not produce any return and can in fact result in the total loss of the amount invested. Venture capitalists make money by investing in companies that succeed more often than they invest in companies that fail. Venture capitalists are willing to lend more money than a bank, but they compensate themselves for the extra risk by charging high rates of interest.

Risk is not the same as gambling in terms of business. Sometimes it is difficult to differentiate. However, taking a business risk is not the same as gambling. Risks taken should be based on analysis and judgment. Gambling is investing money in a situation where the outcome is based on random chance and/or the person simply lends or invests without doing any analysis beforehand. Nevertheless, gambling can be used to explain how interest rates are determined.

\section{Gambling Analogy}

Roulette is a gambling game based on chance. The premise of the game is very simple. A bet is placed on a board (see below). Then a wheel with a ball on it is spun. The wheel has 37 slots where the ball can fall. Depending on which slot the ball actually lands determines if you win or lose your bet. The game is appealing because there are many bets one can place at almost 50-50 odds. However, it is mathematically impossible to develop a system of playing which is risk-free. Assuming the wheel and ball are unbiased and random, there is no way to guarantee a positive return.

Suppose one considers a roulette bet an investment. Suppose a bettor approaches an investor and asks for $\$ 100$ which they will use to place a roulette bet. Assume the following three factors:

1) The principle and interest are due at the end of one year.

2) Interest rate is based on principle less expected value.

3) No external factors are considered.

Given those facts what rate of interest would the investor charge for each of the following three scenarios?

\section{Bet 1}

Placing a bet on a single number is highly risky. There is only a 1 in 37 chance the ball will actually land on the number selected. The probability that the ball will land on the number selected is only $2.7 \%(1 / 37)$. The probability that the ball will not land on the number expected is $97.3 \%$ (36/37). If the ball lands on the number selected, the payout would be $\$ 3500$ ( $\$ 35$ payout multiplied by $\$ 100$ ). Therefore the net gain would be the $\$ 3,500$ payout less the $\$ 100$ bet or $\$ 3,400$. If the ball does not land on the number selected, the entire $\$ 100$ is lost. The expected value of this investment is:

$$
(\$ 3,400 *(1 / 37))+(-\$ 100 *(36 / 37))=\$ 91.90-\$ 97.30=-\$ 5.40
$$

\section{Bet 2}

Now, suppose the bettor approaches the lendor and asks to borrow $\$ 100$ for a bet they will place on the ball landing on one of the following numbers $1,2,3,4,5,6,7,8,9,10,11$,or 12 . This is less risky because there are 12 winning possiblities. The net gain would be $\$ 200$ (\$300 payout less the $\$ 100$ original bet) if the ball lands on any number from 1 through 12 . If it does not, then the $\$ 100$ bet is lost. The expected value of this investment is:

$$
(\$ 200(12 / 37))+(-\$ 100(25 / 37))=\$ 64.86-\$ 67.57=-\$ 2.71
$$

\section{Bet 3}

The least risky bet is to bet on something that simply pays double the bet. Suppose the investor lends the better $\$ 100$ for 
a bet placed on Odd. There are 18 odd numbers, 18 even numbers and a 0 . If the ball lands on an odd number, the gain is $\$ 100$ ( $\$ 200$ payout less $\$ 100$ bet). The expected value of this investment is:

$$
(\$ 100 * 1 / 18)+(-\$ 100(1 / 19)=\$ 5.56-5.26=-.30
$$

The principle and interest due for each investment would be as follows:

Bet $1: \$ 105.40$

Bet $2: \$ 102.71$

Bet $3: \$ 100.30$

Therefore, the interest rate charged for Bets $1-3$ are $5.40 \%, 2.71 \%$, and $.30 \%$ respectively. These interest rates compensate the lendor for the risks associated with each bet. These betting scenarios are meant to explain in very simple terms, the concepts of lending and borrowing. People borrowing money to play roulette is analogous to people borrowing money to maximize the profit of a business. However, there is one major difference: roulette is a game of random chance with only 37 posible outcomes. When a business borrows money, the owner(s) are not going to use the money recklessly (or at least they should not). Instead, their objective is to use the money to grow the business. The owners take calculated risks based on whatever information the owners have at their disposal. Likewise, investors lend money to businesses based on their assessment of the business: its viability, potential, and growth. Also, unlike roulette, the outcomes are not limited to 1 of 37 possible outcomes. The risks are much higher and unpredictable. The amount of profit a company makes could be influenced by only a handful of variables or it could be the result of an almost infinite number of variables.

For the sake of simplicity, assume that a business borrows money in an environment like roulette, where only 1 of 37 outcomes are possible. However, assume that unlike roulette, the borrower can gather data and collect information to make an educated guess as to which of the 37 outcomes will in fact happen. In other words, the bet is not placed on a hunch or guess as to the outcome of a random event. Instead, the money is placed on a 'number' based on thorough analysis. In this scenario the results of the roulette wheel are not random and can actually be predicted based on both quantitative as well as qualitative analysis.

In reality, less-wise investors do gamble to a large extent. The outcome is not typically favorable. The best example of this in the United States was the stock market crash of 1929. At that time, companies trading on the national exchange did not have to provide audited financial statements to the public. Given this lack of information combined with the end result, it is safe to say that people were simply buying stocks based on faulty reasoning or pure guesses. In other words, they were gambling.

The reason no system can be designed to defeat Roulette (or at the very least, insure no losses) is the existence of the zero slot. In the years and months leading up to the stock market crash of 1929, stock prices continued to rise steadily. Momentarily, the country as a whole, lost its collective sanity. Not only were individuals borrowing money from banks to invest in corporate stock, but banks themselves were buying corporate stock. Images of impoverished Americans after the crash are not of people who foolishly invested in the stock market, but rather people who lost all their money because their banks foolishly invested in the stock market and went bankrupt. In simple terms, people forgot that there is no such thing as guaranteed success in business. The investors never accounted for the fact that the ball would eventually land on zero.

\section{Funding-Selling Shares of Ownership}

Large corporations have only a few methods available in regards to raising additional funds. In terms of selling ownership shares they can:

A) Issue more stock - A corporation is a legal entity. When a corporation is formed, it must adhere to the laws of the state in which it is formed. At the time it is formed, a corporation outlines the rules under which it will operate. This is called its Articles of Incorporation. Two key items addressed in the Articles of Incorporation are the number of shares a corporation can issue and the par value (or minimum selling price) of those shares.

B) Issue Bonds - Bonds are formal financial instruments by which corporations borrow large sums of money in a national capital market.

Corporations typically issue fewer shares than they are authorized to issue. Stock is initially offered for sale as part of an initial public offering (IPO). The stock that is sold comprises the stock that is issued and outstanding.

For example, suppose a corporation which is authorized to issue $1,000,000$ shares of common stock ( $\$ 100$ par value) issues 500,000 shares in its IPO for $\$ 125$ per share. Also assume the same company is also authorized to issue 50,000 shares of 7\%, $\$ 100$ par preferred stock. Assume that 10,000 shares of preferred are issued at $\$ 100$ per share.

The amount of capital raised as a result of the IPO of both common and preferred shares is $\$ 62,500,000(500,000$ shares 
$\mathrm{x} \$ 125)$ and $\$ 1,000,000(10,000$ shares $\mathrm{x} \$ 100)$ respectively. The total capital raised is $\$ 63,500,000$. This is an extremely large amount of money, far more than a non-corporate entity could raise through borrowing in return for so small a liability.

In the situation described above, the corporation has issued 500,000 common shares for $\$ 62,500,000$. Each common share represents ownership in the company and entitles the owner to voting rights at the company's annual meeting. The issuance of 10,000 preferred shares for $\$ 100$ raised an additional $\$ 1,000,000$. Preferred stock also represents ownership, but does not entitle the owner to any voting rights. However, it does entitle the owner to a $\$ 7$ (7\% of $\$ 100)$ dividend. The total dividend is $\$ 7 \times 10,000$ or $\$ 70,000$.

There are two kinds of preferred stock: cumulative and non-cumulative. If the preferred stock is cumulative the dividend is owed to the shareholder. This means whether $\$ 7$ is actually paid or not, the shareholder is entitled to \$7. For example, if no dividend is paid in year 1, the shareholder is owed $\$ 14$ in the following year (\$7 current year dividend plus $\$ 7$ dividend owed from the prior year). The amount due to preferred shareholders is the same every year. Common shareholders cannot be paid any dividends until the preferred shareholders are paid their dividends. If the preferred stock is non-cumulative, the amount of d dividends not paid, do not accrue. However, in any particular year, the preferred shareholders must be paid before any dividends are paid to the common shareholders. Corporations do not have to pay all profits out in the form of dividends, but assuming the company's profit grows steadily, common shareholder dividends will exceed preferred shareholder dividends. Whereas preferred shareholders are only owed a fixed dividend, there is no theoretical limit to the amount of dividends paid to common shareholders.

In regards to an established and existing corporation, the need for enormous extra funding does not typically occur. If the corporation wants to raise relatively small amounts of funding, issuing more stock is an option. However, there are drawbacks to issuing each type of stock:

1) Common Stock - Issuing more shares changes the proportional ownership percentages of the corporation. This can shift the voting power amongst the shareholders. The more stock that is issued, the more control of the corporation is surrendered.

2) Preferred Stock - Regardless whether the stock is cumulative or not, some liability in the form of required dividends is established.

\section{Funding- Issuing Bonds}

Instead of issuing more stock, a company can use debt fixed costs financing. The usage of borrowing instruments means that a company is using leverage. The more debt outstanding, the higher the company is leveraged. Growing companies always need more funding in order to finance new projects. New projects are initiated with the hope of increasing revenue and by extension, stockholder equity.

It would be improbable that a company would finance all new endeavors through the issuing of debt. This would create very high financial leverage. It also would not likely fund new endeavors by relying on nothing but the issuance of more equity securities. If a company has $\$ 75,000$ in overall stockholder's equity, and wishes to pursue a new project costing $\$ 50,000$, borrowing the money would be preferable to the shareholders if the company is able to use the borrowed funds to both increase their equity/pay higher dividends and pay off the associated debt.

Here is a basic example: A company borrows $\$ 50,000$ at $6 \%$ for one year. The $\$ 50,000$ was used to increase revenue by $\$ 60,000$ during the year. At the end of the period, $\$ 53,000$ was repaid to satisfy the debt owed $(\$ 50,000$ principal plus $\$ 3,000$ interest). Suppose the $\$ 75,000$ of existing stockholder's equity consists of 1,500 shares of common stock issued at $\$ 50$ (which also happens to be the par value of the stock). The borrowing increased net revenue by $\$ 7,000$ ( $\$ 60,000$ $\$ 53,000$ ). If the $\$ 7,000$ net revenue increase is spread across the existing 1,500 shares, it increases stockholder's equity $\$ 4.67$ per share (all of which can be paid as dividends). If the company had issued 1,000 shares at $\$ 50$ each, to raise the $\$ 50,000$ capital it would have had no debt to pay off at the end of the year. As a result the net revenue would have increased by $\$ 60,000$ as would have stockholder's equity. However, of the $\$ 60,000$ total, $\$ 50,000$ would be a permanent increase to stockholder's equity. The par value of stock is the minimum legal capitalization required. This means that if $\$ 50,000$ is raised by issuing stock at par value, the entire amount is not available to be repaid as dividends. Therefore, only $\$ 10,000$ of the $\$ 60,000$ extra revenue can be paid as dividends. The $\$ 10,000$ extra revenue divided by 2,500 shares equals $\$ 4.00$ per share available for dividends.

In the above example, leverage is clearly preferable to issuing more equity securities. If the company borrows the needed funds, stockholder equity is increased by $\$ 4.67$ per share. If the company issues more stock to raise the needed funds, stockholder equity is only increased $\$ 4.00$ per share. By borrowing the funds instead of issuing debt security, the existing shareholders' relative ownership percentage is not effected and each share increases by $\$ .67$ more. 


\section{Summary and Conclusions}

Businesses evolve over time and the degree of risk and the needs for financing evolve, too. In the early stages of a business, the business is small and most of the financing comes from the entrepreneur and from retained earnings of the business. The next phase of the life of the business may be a partnership with additional investors in the entrepreneurship. After a business achieves a certain size, the owners will incorporate and acquire external financing from venture capital investors, new stockholders' equity, and bonds. Each of these sources of finds has a specific set of risk and return characteristics based on the expected returns and the riskiness of those returns. Because of numerous financial crises, over the last one hundred years, individuals providing external funding to businesses have demanded more and better information. Currently, Sarbanes-Oxley requires both information and evidence that the information is correct. Thus, companies are required to have internal controls that validate the information provided to stakeholders and to have the auditors confirm the quality of the internal control mechanisms.

Risk is discussed in terms of a roulette wheel and each outcome is a matter of chance. In the roulette example, the lendor charges only $5.40 \%$ when the bettor places a bet on a single number. The biggest profit the better can receive is $\$ 3,400$. The lendor gets only $\$ 105.40$ regardless of the outcome. However, a business should not be placing bets based on random outcomes. As explained, the actual business world is more complicated than a situation where there are only 1 of 37 possible outcomes. However, in simplistic terms, if someone places a 'bet' in the actual world, it would be because they have good reason to believe that a certain number or numbers will be the result. If that is the case, and the investor has confidence in the 'bettor's' ability to make the correct choice based on their business acumen, they would not be satisfied with earning only $\$ 5.40$. Instead, they would like a share of the $\$ 3,400$ profit, which should be considerably larger.

Stock holders in a company are the residual claimants of the company and receive everything that remains after all the other stakeholders are paid. These other stake holders include employees, suppliers, lenders, and tax collectors. Because the stock holders assume the most risk, the stock holders anticipate the highest rate of return. SBBI (2014, page 40) shows that historically, equity investors in the US stock market receive about $12 \%$ as the average annual nominal rate of return with a standard deviaiton of $20 \%$ and bond holders receive just under $6 \%$ as the average nominal rate of return with a standard deviaton of about $9 \%$. Thus, the relationship between the risk assumed by various bond and stock investors in a corporation is consistent with the theory that investor who want higher returns must accept higehr risk and investors who want lower risk must settle for lower returns. Fortunately, financial markets allow for all of these diferent preferences.

\section{References}

2014 Ibbotson Stocks. (2014). Bonds, Bills, and Inflation, Market Results for 1926-2013, 2014 Yearbook, Classic Edition, Morningstar.

Brigham, E. F., \& Joel, F. H. (2015). Financial Management, Theory and Practice, Fourteenth Edition, Thomson/Southwestern, Mason, $\mathrm{OH}$.

Brigham, E. F., \& Joel, F. H. (2015). Fundamentals of Financial Management, Concise, Eighth Edition, Harcourt College Publishers, Mason, $\mathrm{OH}$.

Damodaran, A. (2014). Applied Corporate Finance, Fourth Edition, John Wiley\& Sons, Inc.

Gallagher, T. J. (2010). Financial Management: Principles and Practice, 5th Edition, Freeload Press.

McGowan, Carl, B. (2015). Computing Bond Values to Teach Time Value of Money Principles, Southwest Decision Sciences Institute Annual Meeting, Houston.

Ross, S. A., Randolph, W. W., \& Bradford, D. J. (2008). Fundamentals of Corporate Finance, Eighth Edition, McGraw-Hill Irwin, New York.

\section{(cc) $\mathrm{BY}$}

This work is licensed under a Creative Commons Attribution 3.0 License. 